\title{
PENGARUH PENAMBAHAN SERBUK ECENG GONDOK TERHADAP KUAT TEKAN
} BETON

\author{
Oleh \\ Surya Hadi \\ Unizar Mataram \\ Email: Hdsurya11@mail.com
}

\begin{abstract}
Abstrak
Beton merupakan bahan bangunan yang terbuat dari campuran agregat dan pengikat semen. Bentuk paling umum dari beton adalah beton semen Portland, yang terdiri dari agregat mineral (biasanya kerikil dan pasir), semen dan air. Dengan penambahan serbuk eceng gondok pada campuran beton diharapkan bisa menghasilkan beton dengan nilai kuat tekan yang lebih tinggi dibandingkan dengan beton normal. Pada penelitian ini dilakukan pengujian dengan metode destruktif. Pengujian ini bertujuan untuk mengetahui kuat tekan yang ditambahkan dengan serbuk enceng gondok pada beton yang selanjutnya akan dibandingkan dengan beton normal. Pada penelitian dengan tambahan serbuk eceng gondok dipadatkan dengan alat penumbuk. Benda uji berbentuk silinder dengan ukuran diameter $150 \mathrm{~mm}$ dan tinggi $300 \mathrm{~mm}$ sebanyak 24 buah dengan kuat tekan rencana $25 \mathrm{Mpa}$. Kadar serbuk eceng gondok yang ditambahkan pada beton sebesar 0\%, $2 \%, 4 \%$, dan 6\%. Pengujian ini dilakukan setelah beton berumur 28 hari. Prosedur penelitian dilakukan dengan metode destruktif menggunakan alat Compression Testing Machine (CTM). Dari hasil penelitian diperoleh kuat tekan beton normal sebesar 30,38 MPa. Pada penambahan serbuk eceng gondok dengan kadar 2\%, 4\%, dan 6\% diperoleh kuat tekan masing - masing sebesar 21,99 MPa, 18,16 MPa, dan 14,44 MPa. Penambahan serbuk eceng gondok ternyata mengurangi kuat tekan beton. Semakin tinggi persentase penambahan serbuk eceng gondok, kuat tekan beton semakin kecil. Hasil yang didapatkan dari penelitian ini adalah dibawah kuat tekan beton normal.
\end{abstract}

Kata Kunci : Eceng Gondok \& Kuat Tekan

\section{PENDAHUALUAN}

Beton merupakan bahan bangunan yang terbuat dari campuran agregat dan pengikat semen. Bentuk paling umum dari beton adalah beton semen Portland, yang terdiri dari agregat mineral (biasanya kerikil dan pasir), semen dan air. Pada umumnya beton yang paling banyak digunakan dalam konstruksi adalah beton normal. Namun pembuatan beton terus mengalami perubahan dengan penambahan berbagai macam bahan campuran yang diharapkan bisa menghasilkan beton sesuai dengan mutu dan kekuatan yang direncanakan. Salah satunya pembuatan beton dengan campuran bahan eceng gondok.

Pencampuran eceng gondok sebagai zat adiktif beton juga diharapkan salah satu upaya yang cukup espektif untuk menanggulangi populas eceng gondok di kawasan perairan. http://ejurnal.binawakya.or.id/index.php/MBI
Kandungan kimia tumbuhan eceng gondok mempunyai kesamaan dengan unsur pembentuk semen. Hal tersebut memungkinkan pemanfaatan eceng gondok sebagai bahan tambahan pencampuran beton dapat menjadi solusi yang tepat. Dalam hal ini eceng gondok akan dijadikan sebagai bahan pengganti sebagian semen.

Penelitian perencanaan beton dengan menggunakan campuran berbahan tumbuhan juga pernah dilakukan. Salah satunya yaitu pencampuran beton menggunakan abu sekam padi. Ternyata hasil yang dihasilkan selama percobaan tersebut membuat beton memiliki kuat tekan lebih tinggi dan mempunyai penyerapan air yang lebih kecil serta lebih tahan terhadap korosi. Oleh karna itu peneliti mencoba untuk meneliti dengan objek tumbuhan yang berbeda yaitu eceng gondok. Penelitian ini dilakukan untuk

Vol.14 No.1 Agustus 2019 
mengetahui bagaimana pengaruh penambahan serbuk eceng gondok terhadap kuat tekan beton.

Dari beberapa peneliti terdahulu rata-rata mengambil campuran dengan persentase ganjil seperti, $0.25 \%, 0.50 \%, 0.75 \%, 3 \%, 5 \%, 7 \%$ dan $7.5 \%$, sehingga pada penelitian ini menggunakan campuran dengan persentase genap yaitu $2 \%, 4 \%$ dan $6 \%$.

\section{LANDASAN TEORI Pengertian Beton}

Beton merupakan sebuah bahan bangunan yang terbuat dari kombinasi agregat dan pengikat semen. Bentuk paling umum dari beton adalah beton semen Portland, yang terdiri dari agregat mineral (biasanya kerikil dan pasir), semen dan air. Beton yang sudah mengeras dapat juga dikatakan sebagai batuan tiruan, dengan rongga-rongga antara butiran yang besar (agregat kasar atau batu pecah), dan diisi oleh batuan kecil (agregat halus atau pasir), dan pori-pori antara agregat halus diisi oleh semen dan air (pasta semen). Pasta semen juga berfungsi sebagai perekat atau pengikat pada proses pengerasan, sehingga butiran-butiran agregat saling terekat dengan kuat sehingga dapat terbentuklah suatu kesatuan yang padat dan tahan lama.

Beton segar yang baik ialah beton segar yang dapat diaduk, dapat diangkut, dapat dituang, dapat dipadatkan, tidak ada kecendrungan untuk terjadi pemisahan kerikil dari adukan maupun pemisahan air dan semen dari adukan. Beton keras yang baik ialah beton yang kuat, tahan lama, kedap air, tahan aus dan kembang susutnya kecil.

Bahan penyusun beton meliputi air, semen portland, agregat kasar dan halus serta bahan tambah, di mana setiap bahan penyusun mempunyai fungsi dan pengaruh yang berbedabeda.

Pencampuran eceng gondok sebagai zat adiktif beton juga merupakan salah satu upaya yang cukup prospektif untuk menanggulangi gulma eceng gondok di kawasan perairan. Kandungan kimia tumbuhan eceng gondok mengandung unsur SiO2, kalsium ( $\mathrm{Ca})$, Magnesium (Mg), Kalium (K), Natrium ( $\mathrm{Na}$ ),

Vol.14 No.1 Agustus 2019
Chlorida (Cl), Cupper (Cu), Mangan ( $\mathrm{Mg})$, dan Ferum ( $\mathrm{Fe})$ Trikalsium Silikat (C3S), Tetrakalsium Aluminoferit $(C 4 A F)$, Dikalsium Silikat (C2S).

Berdasarkan berat jenis beton dan pemakainnya, beton dapat digolongkan menjadi empat kelompok seperti Tabel 2.1.

Tabel 2.1 Penggolongan Beton Berdasarkan Berat Jenis

\begin{tabular}{|c|c|c|}
\hline Jenis Beton & $\begin{array}{c}\text { Berat } \\
\text { Jenis } \\
\left(\mathbf{k g} / \mathbf{m}^{\mathbf{3}}\right)\end{array}$ & Pemakaian \\
\hline Beton sangat ringan & $<1000$ & Non struktur \\
\hline Beton ringan & $1000-2000$ & Sruktur ringan \\
\hline Beton normal & $2300-2500$ & Struktur \\
\hline Beton berat & $>3000$ & Perisai Sinar X \\
\hline
\end{tabular}

Sumber : Tjokrodimuljo (2003)

\section{Kekuatan Beton}

Kekuatan tekan adalah kemampuan beton untuk dapat menerima gaya per satuan luas (Tri Mulyono, 2004). nilai kekuatan beton diketahui dengan melakukan pengujian kuat tekan terhadap benda uji silinder ataupun kubus pada umur 28 hari yang dibebani dengan gaya tekan sampai mencapai beban maksimum. Beben maksimum didapat dari pengujian dengan menggunakan alat Compression Testing Machine (CTM).

Kuat tekan maksimum $\left(f^{\prime} c\right)$ diberikan oleh persamaan (2.1) berikut :

Keterangan :

$$
f^{\prime} c=\frac{\mathrm{P}}{\mathrm{A}}
$$

$$
\begin{array}{ll}
f^{\prime} c= & \text { Kuat tekan maksimum } \\
\left(\mathrm{N} / \mathrm{mm}^{2} \text { atau } \mathrm{MPa}\right) & \\
\mathrm{P}= & \text { Beban maksimum }(\mathrm{N}) \\
\mathrm{A}= & \text { Luas bidang tekan }\left(\mathrm{mm}^{2}\right)
\end{array}
$$

Menurut Kardiyono Tjokrodimuljo (2012), bahwa kuat tekan beton dipengaruhi faktorfaktor antara lain :

\section{Umur beton}

Kuat tekan beton bertambah tinggi dengan bertambahnya umur. Yang dimaksudkan umur di sini dihitung sejak beton dicetak. Laju kenaikan kuat tekan beton mula-mula cepat, lama-lama laju kenaikan itu semakin lambat, dan laju kenaikan tersebut menjadi relatif sangat kecil setelah berumur 28 hari, sehingga secara umum dianggap tidak naik lagi setelah berumur 28 hari. Oleh karena itu, sebagai standar kuat tekan beton

http://ejurnal.binawakya.or.id/index.php/MBI 
(jika tidak disebutkan umur secara khusus) ialah kuat tekan beton pada umur 28 hari.

\section{Faktor Air Semen (FAS)}

Faktor air semen (FAS) yaitu perbandingan berat air dan berat semen yang digunakan dalam adukan beton. Faktor air semen yang tinggi dapat menyebabkan beton yang dihasilkan mempunyai kuat tekan yang rendah dan semakin rendah faktor air semen yang semakin rendah tidak selalu berarti bahwa kekuatan beton semakin tinggi. Nilai faktor air semen yang rendah akan menyebabkan kesulitan dalam pengerjaan, yaitu kesulitan dalam pelaksanaan pemadatan yang akhirnya akan menyebabkan mutu beton menurun. Oleh sebab itu ada suatu nilai faktor air semen minimum untuk beton normal sekitar 0,4 dan maksimum 0,65 .

Perbandingan faktor air semen dengan kondisi lingkungan dapat dilihat pada Tabel 2.2.

Tabel 2. Perbandingan faktor air semen

\begin{tabular}{|c|c|c|c|}
\hline $\begin{array}{c}\text { Kondisi } \\
\text { Lingkungan }\end{array}$ & Kondisi & $\begin{array}{c}\text { Basah, } \\
\text { Korming } \\
\text { (Berganti- } \\
\text { Ganti) }\end{array}$ & $\begin{array}{c}\text { Dibawah } \\
\text { Pengaruh } \\
\text { Sulfat/Air } \\
\text { Laut }\end{array}$ \\
\hline $\begin{array}{c}\text { koreksi } \\
\text { langsing atau } \\
\text { yang hanya } \\
\text { mempunyai } \\
\text { penutup } \\
\text { tulangan } \\
\text { kurang dari } \\
\text { 25 mm }\end{array}$ & 0,53 & 0,49 & 0,40 \\
\hline $\begin{array}{c}\text { struktur } \\
\text { dinding } \\
\text { penahan } \\
\text { tanah, pilar, } \\
\text { balok, } \\
\text { abutman }\end{array}$ & - & 0,53 & 0,44 \\
\hline $\begin{array}{c}\text { beton yang } \\
\text { tertanam } \\
\text { dalam pilar, } \\
\text { balok, } \\
\text { kolom. }\end{array}$ & - & 0,44 & 0,44 \\
\hline $\begin{array}{c}\text { struktur } \\
\text { lantai balok } \\
\text { diatas tanah }\end{array}$ & - & - & - \\
\hline $\begin{array}{c}\text { beton yang } \\
\text { terlindung }\end{array}$ & - & - & - \\
\hline
\end{tabular}

http://ejurnal.binawakya.or.id/index.php/MBI

\section{Open Journal Systems}

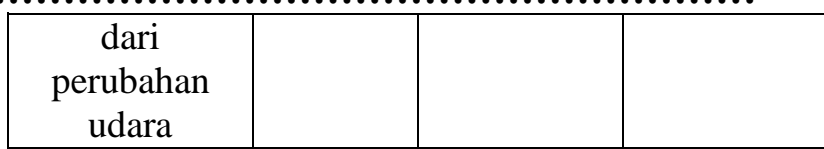

Sumber : Mulyono (2003)

FAS $=\frac{\text { Berat Air }}{\text { Berat Semen }}$

\section{Kepadatan beton}

Kekuatan beton berkurang jika kepadatan beton berkurang. Beton yang kurang padat berarti berisi rongga sehingga kuat tekannya berkurang.

4. Jumlah pasta semen

Pasta semen dalam beton berfungsi untuk merekatkan butir-butir agregat. Pasta semen akan berfungsi secara maksimal jika seluruh pori antar butir - butir agregat terisi penuh dengan pasta semen, serta seluruh permukaan butir agregat terselimuti pasta semen. Jika pasta semen sedikit maka tidak cukup untuk mengisi pori-pori antar butir agregat dan tidak seluruh butir agregat terselimuti oleh pasta semen, sehingga rekatan antar butir kurang kuat, dan berakibat kuat tekan beton rendah. Akan tetapi, jika jumlah pasta semen terlalu banyak maka kuat tekan beton lebih didominasi oleh pasta semen, bukan agregat. Karena umumnya kuat tekan pasta semen lebih rendah daripada agregat, maka jika terlalu banyak pasta semen kuat tekan beton menjadi lebih rendah. Pada nilai FAS sama, variasi jumlah semen juga menggambarkan variasi jumlah pasta semen.

5. Jenis semen

Masing-masing jenis semen Portland (termasuk Semen Portland Pozolan) mempunyai sifat tertentu, misalnya cepat mengeras dan sebagainya, sehingga mempengaruhi pula terhadap kuat tekan betonnya.

6. Sifat agregat

Agregat terdiri atas agregat halus (pasir) dan agregat kasar (kerikil atau batu pecah). Beberapa sifat agregat yang mempengaruhi kekuatan beton antara lain :

1. Kekasaran permukaan, karena permukaan agregat yang kasar dan tidak licin membuat rekatan antara permukaan agregat dan pasta semen lebih kuat daripada permukaan agregat yang halus dan licin.

Vol.14 No.1 Agustus 2019 
2. Bentuk agregat, karena bentuk agregat yang bersudut misalnya pada batu pecah, membuat butir-butir agregat itu sendiri saling mengunci dan sulit digeserkan, berbeda dengan batu kerikil yang bulat.

3. Kuat tekan agregat, karena sekitar $70 \%$ volume beton terisi oleh agregat, sehingga kuat tekan beton didominasi oleh kuat tekan agregat. Jika agregat yang dipakai mempunyai kuat tekan rendah akan diperoleh beton yang kuat tekannya rendah pula.

\section{Material Penyusun Beton}

\section{Agregat}

Agregat merupakan butiran mineral alami yang berfungsi sebagai bahan pengisi dalam campuran mortar atau beton. Agregat ini menempati sebanyak $70 \%-75 \%$ dari volume mortar atau beton. Walaupun namanya hanya sebagai bahan pengisi, akan tetapi agregat sangat berpengaruh terhadap sifat-sifat mortar/betonnya, sehingga pemilihan agregat merupakan suatu bagian penting dalam pembuatan mortar/beton (Tjokrodimuljo, Kardiyono, 2012).

Cara membedakan jenis agregat yang paling banyak dilakukan yaitu dengan didasarkan pada ukuran butiran-butirannya, agregat yang mempunyai ukuran butiran-butiran besar disebut agregat kasar, sedangkan agregat yang ukuran butiran-butiran kecil disebut agregat halus.

Secara umum, agregat kasar sering disebut sebagai kerikil, kericik, batu pecah, atau split. Sedangkan agregat halus disebut pasir, baik berupa pasir alami yang diperoleh langsung dari sungai atau tanah galian, atau dari hasil pemecah batu (Kardiyono, 1996).

Maksud penggunaan agregat dalam campuran beton adalah:

a. Menghemat penggunaan semen.

b. Dengan agregat yang baik dapat tercapainya beton yang baik.

c. Menghasilkan kekuatan beton dengan kekuatan besar.

d. Mengurangi penyusutan pada pengerasan beton.

e. Mudah dikerjakan.

Vol.14 No.1 Agustus 2019

\section{Agregat Kasar}

Menurut SNI 03-2834-1993, agregat kasar adalah kerikil sebagai butiran yang tertahan ayakan 4,75 $\mathrm{mm}$ dan lolos saringan $40 \mathrm{~mm}$.

PBI (1971) menyatakan ketentuan mengenai penggunaan agregat kasar untuk beton harus memenuhi syarat, antara lain :

a. Agregat kasar untuk beton dapat berupa kerikil sebagai hasil desintegrasi alami dari batuan-batuan atau berupa batu pecah yang diperoleh dari pemecahan batu. Pada umumnya yang dimaksudkan dengan agregat kasar adalah agregat dengan besar butir lebih dari $5 \mathrm{~mm}$.

b. Harus terdiri dari butir-butir yang keras dan tidak berpori. Agregat kasar yang mengandung butir-butir pipih hanya dapat dipakai, apabila jumlah butir-butir pipih tersebut tidak melampaui $20 \%$ dari berat agregat seluruhnya. Butir-butir agregat kasar harus bersifat kekal, artinya tidak pecah atau hancur oleh pengaruhpengaruh cuaca, seperti terik matahari dan hujan.

c. Tidak boleh mengandung lumpur lebih dari 1\% (ditentukan terhadap berat kering). Yang diartikan dengan lumpur adalah bagian-bagian yang dapat melalui ayakan 0,063 mm. Apabila kadar lumpur melampaui $1 \%$ maka agregat kasar harus dicuci.

d. Tidak boleh mengandung zat-zat yang dapat merusak beton, seperti zat-zat yang relatif alkali.

e. Kekerasan dari butir-butir agregat kasar diperiksa dengan bejana penguji dari Rudeloff dengan beban penguji 20 t, dengan mana harus dipenuhi syaratsyarat berikut :

1. Tidak terjadi pembubukan sampai fraksi $9,5-19 \mathrm{~mm}$ lebih dari $24 \%$ berat.

2. Tidak terjadi pembubukan sampai fraksi $19-30 \mathrm{~mm}$ lebih dari $22 \%$ berat. Atau dengan mesin pengaus los angelest dimana tidak boleh terjadi kehilangan berat lebih dari $50 \%$. 
f. Agregat kasar harus terdiri dari butir-butir yang beraneka ragam besarnya dan apabila diayak dengan susunan ayakan ditentukan harus memenuhi syarat-syarat berikut :

1. Sisa diatas ayakan $31,5 \mathrm{~mm}$, harus $0 \%$ berat.

2. Sisa diatas ayakan $4 \mathrm{~mm}$, harus berkisar antara 90\% dan 98\% berat.

3. Selisih antara sisa-sisa komulatif diatas dua ayakan berurutan, adalah maksimum $60 \%$ dan minimum $10 \%$ berat.

g. Besar butir agregat maksimum tidak boleh lebih daripada seperlima jarak terkecil antara bidang-bidang samping dari cetakan, sepertiga dari tebal pelat atau tiga perempat dari jarak bersih minimum diantara batang-batang atau berkas-berkas tulangan. Penyimpangan dari pembatasan ini diijinkan, apabila menurut penilaian pengawas ahli, caracara pengecoran beton adalah sedemikian rupa hingga menjamin tidak terjadinya sarang-sarang kerikil.

\section{Agregat Halus}

Menurut SNI 03-2834-1993 agregat halus didefinisikan sebagai butiran ayakan lolos ayakan 4,75 $\mathrm{mm}$ dan tertahan $0,15 \mathrm{~mm}$. Kekasaran pasir dibagi menjadi empat kelompok menurut gradasinya pasir halus, agregat halus, pasir agregat kasar, pasir kasar.

Adapun syarat-syarat dari agregat halus (pasir) yang digunakan menurut PBI (1971), antara lain

a. Agregat halus untuk beton dapat berupa pasir alam sebagai hasil desintegrasi alami dari batuan-batuan atau berupa pasir buatan yang dihasilkan oleh alat-alat pemecah batu.

b. Terdiri dari butir-butir yang tajam dan keras. Butir-butir agregat halus harus bersifat kekal artinya tidak pecah atau hancur oleh pengaruh cuaca, seperti terik matahari dan hujan.

c. Tidak boleh mengandung lumpur lebih dari 5\% (ditentukan terhadap berat http://ejurnal.binawakya.or.id/index.php/MBI kering). Yang diartikan dengan lumpur adalah bagian-bagian yang dapat melalui ayakan $0,063 \mathrm{~mm}$. apabila kadar lumpur melampaui 5\%, ,maka agregat halus harus dicuci.

d. Tidak boleh mengandung bahan-bahan organis terlalu banyak yang harus dibuktikan dengan percobaan warna dari Abrams-Harder (dengan larutan $\mathrm{NaOH}$ ).

e. Tidak boleh menggunakan pasir laut.

\section{Semen Portland}

Semen Portland adalah jenis semen yang paling umum digunakan di seluruh dunia sebagai bahan dasar beton, mortar, plester, dan adukan non-spesialisasi. Semen ini dikembangkan dari jenis lain kapur hidrolik di Britania Raya pada pertengahan abad ke-19, dan biasanya berasal dari batu kapur. Semen ini adalah serbuk halus yang diproduksi dengan memanaskan batu gamping dan mineral tanah liat dalam tanur untuk membentuk klinker, penggilingan klinker, dan menambahkan sejumlah kecil bahan lainnya.

Fungsi utama semen ini sendiri adalah sebagai pengikat butiran-butiran agregat hingga membentuk suatu masa padat dan mengisi rongga-rongga udara diantara butiran agregat. Walaupun komposit semen dalam beton hanya sekitar 10\% namun karena fungsinya sebagai bahan pengikat maka peren semen menjadi penting (Mulyono T, 2003).

Menurut SNI 03-2834-1993 semen Portland adalah campuran semen portal dengan pozolan antara $15 \%-40 \%$ berat total campuran dan kandungan $\mathrm{SiO} 2+\mathrm{AII}-\mathrm{O} 3$ dalam pozolan minimum $70 \%$.

Air

Dalam pemakaian air untuk beton itu sebaiknya air memenuhi syarat - syarat sebagai berikut (Kardiyono, 1996).

a. Tidak mengandung lumpur (benda melayang lainnya) lebih dari 2 gram/liter.

b. Tidak mengandung garam-garam yang dapat merusak beton (asam, zat organik, dan sebagainya) lebih dari 15 gram/liter.

c. Tidak mengandung Chlorida (CI) lebih dari 0,5 gram/liter.

\section{Open Journal Systems}

\section{Vol.14 No.1 Agustus 2019}


d. Tidak mengandung senyawa sulfat dari 1 gram/liter.

\section{Eceng Gondok}

Eceng gondok mengandung kadar air sebesar $90 \%$ berat dengan tingkat reduksi berat dari $10 \mathrm{~kg}$ basah menjadi $1 \mathrm{~kg}$ kering. Dalam keadaan kering eceng gondok mengandung protein kasar 13,03\%, serat kasar 20,6\% lemak $1,1 \%$, abu $23,8 \%$, dan sisanya berupa vortex yang mengandung polisakarida dan mineral-mineral (Soewardi dan Utomo 1975).

Adapun bagian-bagian tanaman yang berperan dalam penguraian air limbah adalah sebagai berikut :

\section{a. Daun}

Daun eceng gondok tergolong dalam hidrophyta yang terletak diatas permukaan air, yang didalamnya terdapat lapisan rongga udara yang berfungsi sebagai alat pengapung tanaman. Zat hijau (klorofil) eceng gondok terdapat dalam kloroplas. Dipermukaan atas daun dipenuhi oleh mulut daun (stomata) dan bulu daun. Rongga udara yang terdapat diakar, batang, dan daun selain sebagai alat penampungan juga berfungsi sebagai tempat penyimpanan $\mathrm{O} 2$ dari proses fotosentesis. Oksigen dari fotosentesis ini digunakan untuk respirasi tumbuhan dimalam hari dengan menghasilkan $O 2$ yang akan terlepas kedalam air (Pandey, 1980).

Dengan kandungan serat yang cukup besar, eceng gondok berpotensi untuk dikembangkan dalam bidang komposit berbasis serat alam. Salah satu aplikasinya adalah untuk pembuatan beton dengan campuran eceng gondok. Hal ini dikarenakan tanaman ini dinilai memiliki kualitas serat yang ulat, kandungan serat cukup tinggi, bahan baku yang melimpah, murah dan mudah didapatkan, serta tidak beracun. Selain itu peningkatan kebutuhan eceng gondok tidak akan mempengaruhi stabilitas pangan, sandang, dan arena tidak berkedudukan sebagai komoditas primer masyarakat.

\section{METODE PENELITIAN}

\section{Lokasi dan waktu Penelitian}

Penelitian ini dilaksanakan di Laboratorium Struktur dan Bahan Fakultas

Vol.14 No.1 Agustus 2019
Teknik Universitas Islam Al - Azhar Mataram dan Universitas Mataram. Penelitian dilakukan dari bulan mei ssampai dengan bulan juli 2019 . Lokasi Pengambilan Sampel Limbah Eceng Gondok yang digunakan berasal dari Embung Batu Jai Lombok Tengah.

\section{Pelaksanaan Penelitian}

\section{Persiapan}

Pada tahap persiapan ini meliputi kegiatan mengumpulkan alat dan bahan yang diperlukan, yaitu semen, agregat halus, agregat kasar, serbuk eceng gondok dan air. Air yang dipakai adalah air bersih dari PDAM.

\section{Pengujian eceng gondok}

Pengujian eceng gondok dilakukan dengan cara :

a. Mencuci bahan eceng gondok untuk memisahkan kandungan lumpur pada akar, batang, dan daunnya.

b. Eceng gondok di jemur selama \pm 1 minggu sampai benar - benar mengering.

c. Setelah mongering kemudian di potong - potong hingga menjadi beberapa bagian, hal ini di maksudkan agar bahan eceng gondok benar - benar kering dan agar lebih mudah dalam proses penumbukan/dihancurkan.

d. Eceng gondok di hancurkan dan dihaluskan menggunakan mesin penggiling kopi sampai benar - benar halus hingga menyerupai semen.

e. Eceng gondok diayak menggunakan saringan $250 \mathrm{~mm}$.

\section{Perencanaan Campuran Beton (Mix Design)}

Perencanaan campuran beton bertujuan untuk mengetahui komposisi atau proporsi bahan-bahan penyusun beton agar memenuhi persyaratan teknis sehingga dapat menghasilkan campuran yang optimal dengan kekuatan maksimum. Kriteria utama dalam Mix Design adalah kekuatan beton (hubungannya dengan faktor air semen) dan kemudahan pekerjaan (workability). Dalam penelitian ini metode yang digunakan metode trial and error untuk mendapatkan mix design yang akan digunakan http://ejurnal.binawakya.or.id/index.php/MBI 
untuk adukan beton. Proposi campuran beton per $1 \mathrm{~m}^{3}$ dapat dilihat pada Tabel 3.1.

Tabel 1 Proporsi Campuran Beton Per $1 \mathrm{~m}^{3}$

\begin{tabular}{|c|c|c|c|c|c|c|}
\hline \multirow{2}{*}{$\begin{array}{c}\text { Kode Benda } \\
\text { Uji }\end{array}$} & Semen & Pasir & Kerikil & Air & \multicolumn{2}{|c|}{$\begin{array}{c}\text { Serbuk eceng } \\
\text { gondok }\end{array}$} \\
\cline { 2 - 7 } & $\mathbf{( K g )}$ & $\mathbf{( K g )}$ & $\mathbf{( K g )}$ & $\mathbf{L i t e r}$ & $\mathbf{( \% )}$ & $\mathbf{( K g )}$ \\
\hline BN & 395,65 & 699,74 & 1049,61 & 205 & 0 & 0 \\
\hline BT 1 & 395,65 & 699,74 & 1049,61 & 205 & 2 & 7,913 \\
\hline BT 2 & 395,65 & 699,74 & 1049,61 & 205 & 4 & 15,83 \\
\hline BT 3 & 395,65 & 699,74 & 1049,61 & 205 & 6 & 23,74 \\
\hline
\end{tabular}

Catatan : Masing masing uji sebanyak 6 benda uji

\section{HASIL DAN PEMBAHASAN}

\section{Hasil Pemeriksaan Bahan Penyusun Beton}

Dari hasil pemeriksaan bahan penyusun beton yang dilaksanakan di Laboratorium Struktur dan Bahan Fakultas Teknik Universitas Islam Al-Azhar Mataram diperoleh hasil pada Tabel 4.1.

Tabel 4.1 Hasil Uji Agregat

\begin{tabular}{|l|l|c|c|l|c|}
\hline No & Bahan & Berat satuan lepas & $\begin{array}{c}\text { Berat satuan } \\
\text { padat }\end{array}$ & $\begin{array}{c}\text { Kadar } \\
\text { lumpur }\end{array}$ & $\begin{array}{c}\text { Modulus } \\
\text { kehalusan }\end{array}$ \\
\hline 1 & Pasir & $1,360 \mathrm{gr} / \mathrm{cm}^{3}$ & $1,549 \mathrm{gr} / \mathrm{cm}^{3} 1$ & $2,92 \%$ & 2,79 \\
\hline 2 & Kerikil & $1,491 \mathrm{gr} / \mathrm{cm}^{3}$ & $1,561 \mathrm{gr} / \mathrm{cm}^{3}$ & $0,98 \%$ & 6,46 \\
\hline
\end{tabular}

Dari pemeriksaan pada agregat halus (pasir) dan kerikil semuanya memenuhi persaratan beton (Tjokrodimuljo, 2010).

\section{Hasil Pengujian Beton \\ Nilai Slump Beton}

Pemeriksaan slump pada penelitian ini bertujuan untuk mengetahui seberapa besar tingkat kelecekan (workability) adukan beton. Nilai slump rata-rata yang didapatkan pada beton normal adalah $8,75 \mathrm{~cm}$. Sedangkan nilai slump rata - rata untuk beton dengan campuran serbuk eceng gondok dengan kadar 2\% (BT 1), 4\% (BT 2), dan 6\% (BT 3) berturut - turut adalah 7,5 cm, $6,9 \mathrm{~cm}$, dan $6,1 \mathrm{~cm}$. Nilai slump tersebut masuk ke dalam slump rencana yakni $6-18 \mathrm{~cm}$ untuk beton struktural.

\section{Uji Kuat Tekan}

Pengujian kuat tekan dilakukan dengan menggunakan alat Compression Testing Machine (CTM) di Laboratorium Struktur dan Bahan Fakultas Teknik Universitas Mataram. Pengujian dilakukan setelah beton mengalami perawatan dan mencapai umur 28 hari. Hasil yang digunakan dalam menentukan kuat tekan benda uji adalah beban maksimum yang mengakibatkan benda uji tidak mampu lagi menerima beban dan benda uji mengalami retak. Hasil pengujian dapat dilihat pada Tabel 4.2.

Tabel 4.2 Hasil Pengujian Kuat Tekan Beton

\begin{tabular}{|c|c|c|c|c|c|c|}
\hline $\begin{array}{c}\text { Kode } \\
\text { Benda } \\
\text { Uji }\end{array}$ & $\begin{array}{c}\text { No } \\
\text { Benda } \\
\text { Uji }\end{array}$ & $\begin{array}{c}\text { Kadar } \\
\text { Eceng Gondok } \\
(\%)\end{array}$ & $\begin{array}{c}\text { Luas } \\
(\mathrm{A}) \\
\left(\mathrm{mm}^{2}\right)\end{array}$ & $\begin{array}{c}P \\
\operatorname{Max}(N)\end{array}$ & $\begin{array}{c}\mathbf{f}^{\prime} \mathbf{c} \\
\mathrm{Pmax} / \mathrm{A}(\mathrm{Mpa})\end{array}$ & $\begin{array}{c}\text { f' Rata-Rata } \\
\text { (Mpa) }\end{array}$ \\
\hline \multirow{6}{*}{ BN } & 1 & \multirow{6}{*}{0} & 17662.5 & 570000 & 32.27 & \multirow{6}{*}{30.38} \\
\hline & 2 & & 17662.5 & 540000 & 30.57 & \\
\hline & 3 & & 17662.5 & $\mathbf{5 5 0 0 0 0}$ & 31.14 & \\
\hline & 4 & & 17662.5 & 520000 & 29.44 & \\
\hline & 5 & & 17662.5 & 530000 & 30.01 & \\
\hline & 6 & & 17662.5 & 510000 & 28.87 & \\
\hline \multirow{6}{*}{ BT 1} & 1 & \multirow{6}{*}{2} & 17662.5 & 415000 & 23.50 & \multirow{6}{*}{21.99} \\
\hline & 2 & & 17662.5 & 360000 & 20.38 & \\
\hline & 3 & & 17662.5 & 410000 & 23.21 & \\
\hline & 4 & & 17662.5 & 385000 & 21.80 & \\
\hline & 5 & & 17662.5 & 390000 & 22.08 & \\
\hline & 6 & & 17662.5 & 370000 & 20.95 & \\
\hline \multirow{6}{*}{ BT 2} & 1 & \multirow{6}{*}{4} & 17662.5 & 330000 & 18.68 & \multirow{6}{*}{18.16} \\
\hline & 2 & & 17662.5 & 370000 & 20.95 & \\
\hline & 3 & & 17662.5 & 320000 & 18.12 & \\
\hline & 4 & & 17662.5 & 300000 & 16.99 & \\
\hline & 5 & & 17662.5 & 295000 & 16.70 & \\
\hline & 6 & & 17662.5 & 310000 & 17.55 & \\
\hline \multirow{6}{*}{ BT 3} & 1 & \multirow{6}{*}{6} & 17662.5 & 280000 & 15.85 & \multirow{6}{*}{14.44} \\
\hline & 2 & & 17662.5 & 265000 & 15.00 & \\
\hline & 3 & & 17662.5 & 210000 & 11.89 & \\
\hline & 4 & & 17662.5 & 235000 & 13.31 & \\
\hline & 5 & & 17662.5 & 250000 & 14.15 & \\
\hline & 6 & & 17662.5 & 290000 & 16.42 & \\
\hline
\end{tabular}

Uji Kuat Tekan

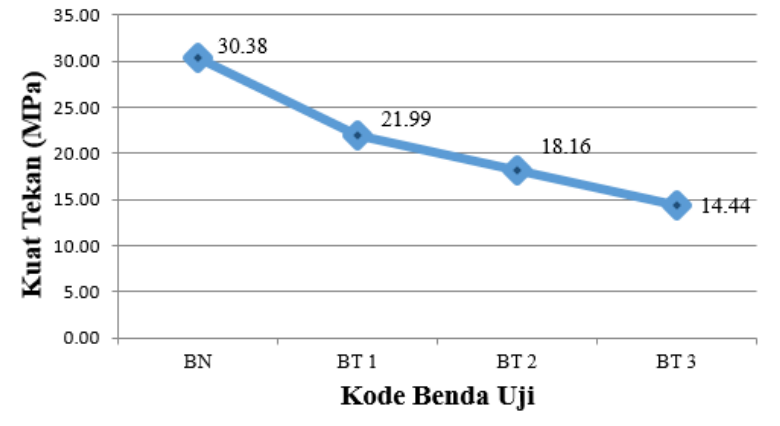

Gambar 4.1 Grafik hasil pengujian kuat tekan

Pada Gambar 4.1 menunjukkan bahwa hasil kuat tekan maksimum yaitu pada beton normal sebesar 30,38 Mpa, hal ini dikarenakan beton normal tanpa penambahan bahan tambah, sehingga menghasilkan beton yang homogen, dan berpengaruh terhadap kuat tekan yang dihasilkan. Sedangkan untuk beton dengan penambahan serbuk eceng gondok dengan kadar 2\%, $4 \%$ dan 
$6 \%$ diperoleh kuat tekan rata-rata berturut-turut sebesar 21,99 Mpa, 18,16 Mpa, dan 14,44 Mpa..Pada beton dengan penambahan serbuk eceng gondok dengan kadar $2 \%, 4 \%$, dan $6 \%$ berturut-turut terus mengalami penurunan hal ini dikarenakan bahan tambah serbuk eceng gondok menyerap air dengan cepat dan menyebabkan nilai kuat tekan beton semakin menurun.

Dari hasil kuat tekan tersebut diketahui bahwa kuat tekan beton normal lebih besar dibandingkan dengan beton dengan penambahan serbuk eceng gondok. Perbedaan kuat tekan antara beton normal dan beton dengan penambahan serbuk eceng gondok tersebut disebabkan karena pada beton normal tanpa penambahan bahan tambah, sehingga menghasilkan beton yang homogen, dan berpengaruh terhadap kuat tekan yang dihasilkan. Pada beton dengan penambahan serbuk eceng gondok dengan kadar $2 \%, 4 \%$, dan $6 \%$ berturutturut terus mengalami penurunan hal ini dikarenakan bahan tambah serbuk eceng gondok menyerap air dengan cepat sehingga proses hidrasi semen belum sempurna yang menyebabkan nilai kuat tekan beton semakin menurun.

Kuat tekan beton dengan penambahan serbuk eceng gondok dengan kadar $6 \%$ memiliki kuat tekan terkecil, hal ini disebabkan karena kadar serbuk eceng gondok yang ditambahkan semakin banyak.

\section{PENUTUP \\ Kesimpulan}

Dari hasil pengujian yang telah dilakukan dapat disimpulkan bahwa kuat tekan beton normal (BN) sebesar 30,38 Mpa. Pada penambahan serbuk eceng gondok dengan kadar 2\% (BT1), 4\% (BT2), dan 6\% (BT3) diperoleh kuat tekan masing-masing sebesar 21,99 Mpa, 18,16 Mpa, dan 14,44 Mpa. Kuat tekan beton normal lebih tinggi dibandingkan dengan beton dengan penambahan serbuk eceng gondok. Kuat tekan beton dengan penambahan serbuk eceng gondok dengan kadar 2\%, 4\%, dan $6 \%$ terus mengalami penurunan. Kuat tekan beton dengan penambahan serbuk eceng gondok dengan kadar
$6 \%$ memiliki kuat tekan yang paling kecil atau terendah, hal ini disebabkan karena kadar serbuk eceng gondok yang di tambahkan semakin banyak sehingga mempengaruhi nilai kuat tekan pada beton tersebut.

\section{Saran}

Untuk penelitian selanjutnya disarankan untuk memakai faktor air semen yang lebih tinggi dan kisaran prosentase yang tidak terlalu besar.

\section{DAFTAR PUSTAKA}

[1] Ir. Kardiyono, 1996, Syarat-syarat Pemakaian Air untuk Beton.

[2] Ir. Kardiyono Tjokrodimuljo, 2004, Teknologi Beton.

[3] Ir. Kardiyono Tjokrodimuljo, 2012, FaktorFaktor yang mempengaruhi Kuat Tekan Beton.

[4] Moenandir, (1990), Manfaat Tumbuhan Eceng Gondok.

[5] Mulyono, (2003), Perbandingan Faktor Air Semen.

[6] Mulyono, T., (2005), Teknologi Beton, C.V Andi Offset, Yogyakarta.

[7] Mulyono (2015), Bahan Pembuatan Beton.

[8] Pandey, 1980, Bagian-bagian Tumbuhan Eceng Gondok yang Berperan dalam Penguraian Air Limbah.

[9] Paul Nugraha dan Antoni (2007), Syaratsyarat pemakaian air untuk beton.

[10] SNI-S-04-1989-F, Kategori Semen Portland Sesuai dengan Tujuan Pemakaiannya.

[11] SNI 03-2834-1993, Definisi semen Portland dan Agregat Kasar.

[12] SNI 15-7064-2004, Definisi Semen Portland Komposit.

[13] Soewardi dan Utomo (1975), Kandungan Bahan Eceng Gondok.

[14] Tjokrodimuljo (2003), Penggolongan Beton Berdasarkan Berat Jenis.

[15] Tri Mulyono, 2004, Definisi Kuat Tekan Beton.

[16] Tjokrodimuljo, (2010), Pemeriksaan Berat Jenis Agregat.

[17] Tjokrodimuljo, Kardiyono,( 2012), Definisi Agregat.

http://ejurnal.binawakya.or.id/index.php/MBI 